\title{
RR soybean seed quality after application of glyphosate in different stages of crop development ${ }^{1}$
}

\author{
Leandro Paiola Albrecht2*, André Prechlak Barbosa ${ }^{2}$, André Felipe Moreira Silva ${ }^{2}$, \\ Matheus Akiyama Mendes ${ }^{2}$, Alfredo Júnior Paiola Albrecht ${ }^{3}$, Marizangela Rizzatti Ávila ${ }^{4}$
}

\begin{abstract}
In consequence of several studies and speculations concerning the issue of RR transgenic soybean after the application of glyphosate, additional scientific investigations became necessary to clarify the actual viability of the product use when applied in different developmental stages of the soybean crop. Therefore, this study was aimed to evaluate the physiological quality as well as seed health quality of RR soybean subjected to application of the herbicide glyphosate in different phonological stages of the transgenic soybean, cultivar CD 219RR. For this, an experiment with a complete block experimental design with treatments randomly distributed within the block, with four replications, was carried out. The assessed treatments were foliar sprayings of glyphosate in three increasing dosages [ 0 (control); 1,440 $\mathrm{g} \mathrm{ha}^{-1}$; and 2,880 $\mathrm{g} \mathrm{ha}^{-1}$ ] of acid equivalent, applied in two crop developmental stages: vegetative (V6) and reproductive (R2). The variables assessed were: germination; first count of germination; fresh and dry mass of seedlings, lengths of seedling and root; vigor and viability by the tetrazolium test; and seed health quality. Glyphosate application may adversely affect physiological quality of RR soybean seeds, when applied in dosages varying from 1,440 to 2,880 $\mathrm{g}$ acid equivalent per hectare at the stages V6 and R2.
\end{abstract}

Index terms: Glycine max, transgenic seed, performance, herbicide.

\section{Qualidade das sementes de soja RR após aplicação de glyphosate em diferentes estádios de desenvolvimento da cultura}

\begin{abstract}
RESUMO - Em virtude de estudos e especulações envolvendo a questão da soja transgênica (RR) após a aplicação de glyphosate, se fez necessário a busca de informações científicas que permitam diagnosticar a real viabilidade do uso do glyphosate aplicado em diferentes estádios fenológicos da cultura. Deste modo, o objetivo deste estudo foi avaliar a qualidade fisiológica e sanitária das sementes de soja RR após a aplicação do herbicida glyphosate na cultura da soja transgênica, cultivar CD 219RR. Para tanto, foi desenvolvido um ensaio em delineamento de blocos completos com tratamentos casualizados, com quatro repetições, em que os tratamentos avaliados consistiram da pulverização foliar contendo glyphosate, em três doses crescentes $(0$, 1.440 e $2.880 \mathrm{~g}$ de equivalente ácido por hectare), aplicados em dois estádios de desenvolvimento da cultura: vegetativo V6 e reprodutivo R2. As variáveis avaliadas foram: germinação; primeira contagem de germinação; massa fresca e seca de plântulas; comprimento de plântulas e raízes; viabilidade e vigor, pelo teste de tetrazólio; e qualidade sanitária das sementes. A aplicação de glyphosate pode afetar negativamente a qualidade fisiológica das sementes de soja, quando aplicado em doses de 1.440 a $2.880 \mathrm{~g}$ do equivalente ácido do produto por hectare, nos estágios fenológicos: vegetativo V6 e reprodutivo R2
\end{abstract}

Termos para indexação: Glycine max, semente transgênica, desempenho, herbicida.

${ }^{1}$ Submitted on 12/23/2010. Accepted for publication on 01/21/2012.

${ }^{2}$ Departamento de Ciências Agronômicas, Universidade Estadual de Maringá, 87507-190-Umuarama, PR, Brasil.

${ }^{3}$ Departamento de Agronomia, Universidade Estadual de Maringá,
87020-170-Maringá, PR, Brasil.

${ }^{4}$ Instituto Agronômico do Paraná (IAPAR), Caixa Postal 112, 85825-000-Santa Tereza do Oeste, PR, Brasil.

*Corresponding author<lpalbrecht@yahoo.com.br> 


\section{Introduction}

The soybean crop has gone through intense agrotechnologic modifications that allow for productivity increases and reductions in production costs. This event has required constant reformulation and technological adaptations, such as the management of glyphosate herbicide that is applied via foliar spray on the RR soybean crop fields. It has been pondered, however, that the glyphosate can have some stressor effect on RR soybean plants for which it should be selective, i.e., should be not have any herbicide effect; and any stress exerts negative effect on normal growth and on development of plant species (Taiz and Zeiger, 2009).

Some studies, for example, have related the use of glyphosate in post-emergence on RR transgenic soybean with problems of biological fixation of nitrogen and mineral nutrition of soybean plants as a whole, as the case of the manganese, whose effects confirm the possibility of problems occurrence (Gordon, 2006; Huber, 2007). Other nutrients, such as $\mathrm{N}, \mathrm{Ca}, \mathrm{Mg}, \mathrm{Fe}$, and $\mathrm{Cu}$ may have their levels modified with the application of glyphosate (Reddy and Zablotowicz, 2003; Huber, 2007; Gordon, 2006; Santos et al., 2007a; Santos et al., 2007b). Plants with nutritional problems tend produce malformed seeds what implies in physiologically less suitable seeds (Marcos-Filho, 2005). Likewise, plants with nutritional problems tend to present troubles in their metabolism from which impairments may come about on their physiological system; and in consequence, damages to quality of seeds. Manganese, for example, acts as a co-factor activating circa 35 different enzymes commanding since aromatic amino acids biosynthesis until secondary products such as lignin and flavonoides. Low concentrations of lignin and flavonoides are also responsible by decreased resistance to diseases (Rizzardi et al. 2003; Gordon, 2006; Gordon, 2007; Rahe, 2007).

It is known that RR soybean plants, after treatment with glyphosate, havewithintheresiduesofaminomethylphosphonic acid (AMPA), resulting from the product degradation (Arregui et al., 2003; Reddy et al., 2004). Besides, although glyphosate is usually scarcely metabolized by plants, the AMPA is the main metabolite found in RR soybean seeds treated with such herbicide (Duke et al., 2003). However, it was only proven that certain abnormalities, such as reduction on chlorophyll content as well as plant growth, may be caused by the glyphosate degradation into AMPA. Increases in the glyphosate dosages may increase content of AMPA, thus intensifying the phytotoxic effects of this metabolite (Reddy et al., 2004). The AMPA accumulates in the seeds (Duke et al., 2003) and therefore its presence in soybean seeds may be a noxious agent for the physiology of seeds, causing disturbances that may result on production of abnormal plants. According to Hoagland (1980), the AMPA has a behavior apparently different from glyphosate for being less active, but it can be toxic, hence causing alterations on soybean seedlings.

There are reports, such as that of Albrecht and Ávila (2010) on the increase on incidence of the fungus Cercospora kikucii, supposing that such occurrence happens in function of lower tolerance to soybean pathogens with the application of increasing dosages of glyphosate. These same authors have also reported the observation of a decreasing negative linear trend on seed physiological quality with the increments in the dosages of glyphosate that are justified by the deleterious effect of these high dosages, even on soybean cultivars resistant to this herbicide. They also affirm that is supposed that interferences on the physiological performance, as well as on seed health, may happen due to possible damages caused by the use of glyphosate, applied alone or in tank mixtures with other herbicides, on RR soybean plants.

Late applications of glyphosate, as well as in high dosages, are eventually indentified in the field, especially when farmers lose the exact moment of application or in managing tolerant weeds, respectively. Considering such particularities identified under field conditions, the need of further studies for characterizing the consequences of this procedure become essential.

By assuming the remarkable importance of an adequate management of the herbicide glyphosate and based on assumptions (and also on some proven cases) of adverse effects arising from its improper use on the RR soybean, it is necessary to search for scientific information for diagnosing the actual feasibility of using this herbicide and its implications on the quality of seed produced; mainly when glyphosate is applied in different phenological stages of the soybean crop.

In face of the foregoing, this study was aimed at assessing physiological quality, as well as the seed health quality, of the transgenic soybean, cv. CD 219RR, produced under the use of glyphosate applied in different phenological stages of the soybean crop.

\section{Material and Methods}

The experiment was carried out in the farm of the Advanced Center of Umuarama(CAU), of the State University 
of Maringá (UEM) (234' S latitude; 5314' W longitude; and $403 \mathrm{~m}$ altitude), in the municipality of Umuarama, northwestern region of Paraná State, Southern Brazil. The soil at the experimental area is classified as a typical Dystrophic Red Oxisol, with sandy texture. According to Köppen classification, the predominant climate in the area is the Cfa-Humid Subtropical Mesothermic.

The experimental area was desiccated before sowing with $4.0 \mathrm{~L} \mathrm{ha}^{-1}$ of the herbicide Roundup Original ${ }^{\circledR}$ (Glyphosate) mixed with $0.5 \mathrm{~L} \mathrm{ha}^{-1}$ of the Assist ${ }^{\circledR}$ mineral oil. The sowing fertilization, as well as all subsequent procedures of crop management, was performed according to recommendations of Embrapa Soybean (2008). Assessments of physiological quality and health quality of seeds were performed in the Laboratory of Seed Technology of CAU, of the Center of Agrarian Sciences of UEM.

The RR transgenic soybean, cultivar CD 219RR, belonging to the middle maturity group, was used in the experiment. The sowing procedure was performed in November of the 2009/2010 agricultural year, with a spacing of $0.45 \mathrm{~m}$ between rows and a sowing density of 16 seeds per linear meter, in a no-till system area. The plots were composed of six rows with $5 \mathrm{~m}$ length each. For the assessments, an area of $5.4 \mathrm{~m}^{2}$ was used within each plot. Hence, four rows of $3 \mathrm{~m}$ length each, discarding $1 \mathrm{~m}$ at the extremities of each row were used for the assessments.

The treatments assessed were constituted of foliar sprays of solutions containing glyphosate (commercial product: Roundup Ready ${ }^{\mathbb{B}}$ ), applied at two stages of soybean crop development: vegetative stage V6 and reproductive stage R2. Three doses of acid equivalent: 0 (control); 1,440 $\mathrm{g} \mathrm{ha}^{-1}$; and $2.880 \mathrm{~g} \mathrm{ha}^{-1}$, were used in each developmental stage. The foliar applications were performed with the aid of a $\mathrm{CO}_{2}$ propelled costal sprayer at a constant pressure of 2 bar (or $29 \mathrm{psi}$ ), equipped with a lance containing a fanshaped nozzle of TeeJet ${ }^{\circledR}$ series, XR 11002 type. The sprays were performed at $50 \mathrm{~cm}$ from the target, at a speed of $1 \mathrm{~m} \mathrm{sec}^{-1}$, reaching a spraying range of $50 \mathrm{~cm}$ width, and providing a mixture volume of $200 \mathrm{~L} \mathrm{ha}^{-1}$.

Plants were manually harvested 7 days after reaching the reproductive stage R8 (full maturity). After harvesting, the pods were threshed in a stationary thresher, cleaned by sieving, dried under room environmental conditions, and packaged into Kraft paper bags.

Physiological quality of seeds was assessed by tests: germination (Brasil, 2009); first count of germination (Brasil, 2009); fresh and dry mass of seedlings (Nakagawa, 1999); lengths of seedlings and roots (Nakagawa, 1999); and tetrazolium (França-Neto et al., 1998). Seed health quality was assessed by the Blotter Test (Henning, 1994; Goulart, 1997).

A complete block experimental design was used, with the randomly distributed treatments within each block and arranged into a $2 \times 3$ factorial scheme (2 stages of development x 3 herbicide dosages). Once the basic assumptions were fulfilled, data were subjected to ANOVA and, independently of significance of the $\mathrm{F}$ test $(\mathrm{p} \leq 0.05)$ in the interactions; the developments needed to diagnose possible effects of interactions were applied. The F test was conclusive for comparison of developmental stage effects means. Regression analysis was used to verify the behavior of variables as a function of doses of glyphosate, applied via foliar spray, at $5 \%$ probability.

\section{Results and Discussion}

From the statistical analysis of data it was possible to detect significant differences $(p \leq 0.05)$ only within variable referring to physiological quality of seeds. For the variables germination and vigor, assessed by first count of germination in the germination test (Table 1) it was possible to verify differences only if the computations of developmental stages were performed within dosages by splitting their components, for the germination variable, as well as for dosages, which had to be split for computation within developmental stages. Oppositely, vigor has only presented differences for the isolated effect of dosages, thus characterizing a decreasing negative linear regression (Figure 1) with angular coefficient of 0.004955 , i.e., decreasing in $0.004955 \%$ the seed vigor for each gram acid equivalent applied per hectare.

By splitting doses within stages, for the variable percentage of germination, fit was found to linear regression models, where the decrease on seed germination was shown for herbicide applications in the different development stages (V6 and R2) with the increase in doses of glyphosate (Figure 2). Such decreases, either for vigor or percent of germination, ratify the information reported by Albrecht and Ávila (2010).

The low percent values of germination and vigor, assessed by the germination test, are supposedly attributed to unfavorable climatic conditions of the region for seed production with high standards of physiological quality associated with the incidence of pathogenic microorganisms. Especially for the 2009/2010 agricultural year during which heavy rainfalls and high temperatures have occurred during maturation and harvest periods; what 
may have contributed for acceleration of deterioration process, thus depreciating the physiological potential of seeds therein produced. This information has been stressed in a book published by Marcos-Filho (2005).

Table 1. Mean values obtained for germination and vigor of seeds of transgenic soybean RR, cultivar CD 219RR, harvested after application of different doses of glyphosate in two different soybean phenological stages (V6 and R2).

\begin{tabular}{ccccc}
\hline & \multicolumn{3}{c}{$\begin{array}{c}\text { Germination } \\
(\%)\end{array}$} & \multicolumn{2}{c}{$\begin{array}{c}\text { Vigor (first count of germination) } \\
(\%)\end{array}$} \\
\cline { 2 - 5 }$\left(\mathrm{g} \mathrm{hase}^{-1}\right)$ & Vegetative & Reproductive & Vegetative & Reproductive \\
& V6 & R2 & V6 & $45.66^{\text {ns }}$ \\
\hline 0 (control) & $57.83 \mathrm{~A}^{*}$ & $60.00 \mathrm{~A}^{*}$ & $39.87^{\text {ns }}$ & 38.94 \\
1,440 & $45.17 \mathrm{~B}$ & $57.50 \mathrm{~A}$ & 33.50 & 25.50 \\
2,880 & $48.87 \mathrm{~A}$ & $37.50 \mathrm{~B}$ & 31.50 & 36.70 \\
\hline Mean & 50.62 & 51.67 & 34.96 & \\
\hline
\end{tabular}

*Means followed by the same letter in the column do not statistically differ between each other by $\mathrm{F}$ test at $5 \%$ probability; ${ }^{\text {ns }}$ statistically non significant.

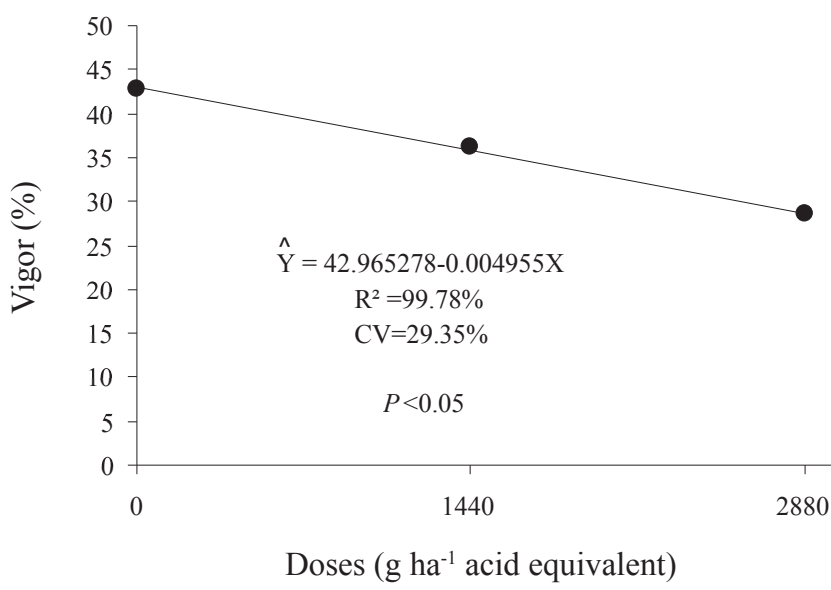

Figure 1. Linear regression for the seed vigor variable (assessed by the first count of germination test) of RR transgenic soybean, cultivar CD 219RR, as a function of application of different doses of glyphosate.

It can be observed on Table 2 and Figures 3 and 4, results referring to seed physiological quality by tetrazolium test, which differentiates seed Vigor (Tetrazolium 1-3) from seed viability (tetrazolium 1-5). By these assessments, becomes also obvious the negative effect of using increasing dosages of glyphosate on RR soybean (especially the $2,800 \mathrm{~g} \mathrm{ha}^{-1}$ dose) on seed quality. It can be likewise observed that, differently from results presented on Table 1, when the highest dose is applied at the reproductive stage $\mathrm{R} 2$, its effect is especially aggressive and deleterious to seed physiology. The bestfit was found for a decreasing negative linear regression within the reproductive stage $\mathrm{R} 2$, for both variables previously mentioned.

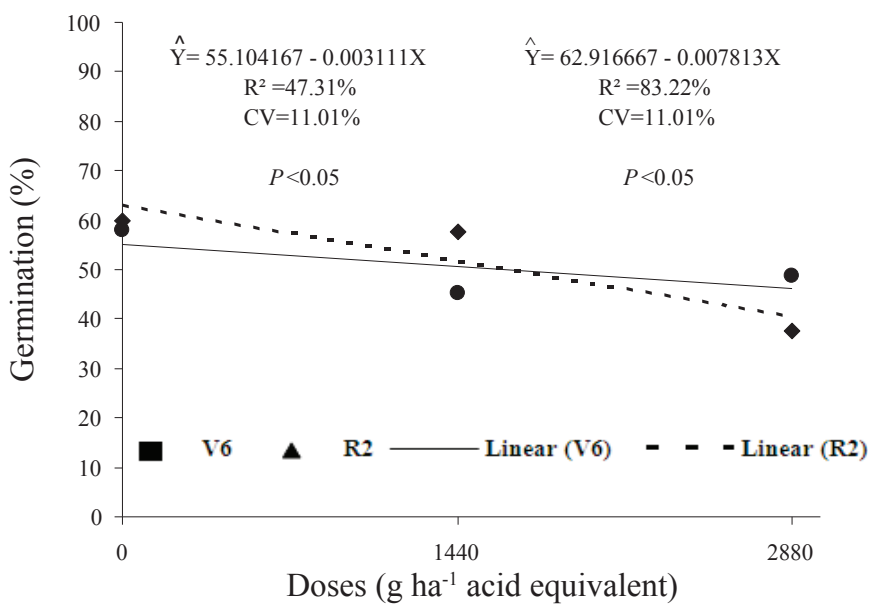

Figure 2. Linear regression for the seed germination variable of RR transgenic soybean, cultivar CD 219RR, as a function of application of different doses of glyphosate in two different soybean phenological stages: vegetative V6 and reproductive R2.

Differences between viability and vigor, determined by tests of germination and tetrazolium, can be attributed to infections caused by fungi in the seeds. Problems of germination under laboratory conditions can be ascribed to the fungus Phomopsis sp. (Henning and França-Neto, 1980). According to França-Neto and Henning (1992), confirming Pereira et al. (2000), the fungus Fusarium spp. can also reduce seed germination and its effects can be added to those of the fungus Phomopsis sojae. Among the various species within the genus Fusarium, the species $F$. semitectum is the most common in soybean seeds in Brazil and it can affect germination during the standard germination test in the laboratory; similarly to the fungus Phomopsis spp. 
Table 2. Mean values obtained for viability and vigor by the tetrazolium test of seeds of transgenic soybean RR, cultivar CD 219RR, harvested after application of different doses of glyphosate in two different soybean phenological stages.

\begin{tabular}{ccccc}
\hline \multirow{2}{*}{$\begin{array}{c}\text { Dose } \\
\left(\mathrm{g} \mathrm{ha}^{-1}\right)\end{array}$} & \multicolumn{2}{c}{$\begin{array}{c}\text { Viability (\%) } \\
\text { (Tetrazolium 1-5) }\end{array}$} & \multicolumn{2}{c}{$\begin{array}{c}\text { Vigor (\%) } \\
\text { (Tetrazolium 1-3) }\end{array}$} \\
\cline { 2 - 5 } & Vegetative & Reproductive & Vegetative & Reproductive \\
& V6 & R2 & $68.50 \mathrm{~A}^{*}$ & $80.75 \mathrm{~A}^{*}$ \\
\hline (control) & $92.50 \mathrm{~A}^{*}$ & $95.50 \mathrm{~A}^{*}$ & $48.56 \mathrm{~A}$ & $60.99 \mathrm{~A}$ \\
1,440 & $89.66 \mathrm{~A}$ & $91.13 \mathrm{~A}$ & $71.33 \mathrm{~A}$ & $43.28 \mathrm{~B}$ \\
2,880 & $90.75 \mathrm{~A}$ & $75.38 \mathrm{~B}$ & 62.80 & 61.67 \\
\hline
\end{tabular}

*Means followed by the same letter in the columns do not statistically differ from each other by the F test at $5 \%$ probability.

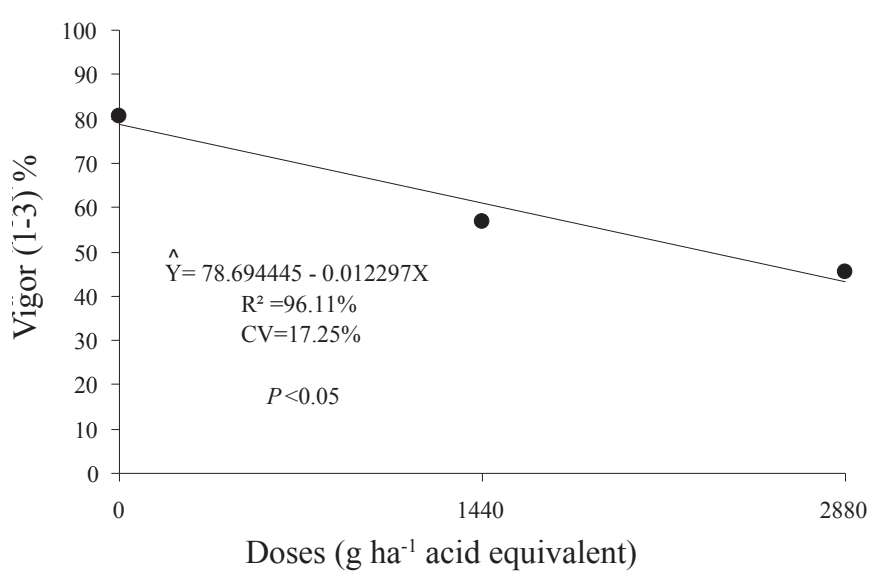

Figure 3. Linear regression for the vigor variable (1-3), assessed by tetrazolium test in seeds of RR transgenic soybean, cultivar CD 219RR, as a function of application of different doses of glyphosate at soybean reproductive stage R2.

The seedlings performance, expressed by the variables: length of seedlings and roots (Table 3 and Figure 5) and fresh and dry mass of seedlings (Table 4 and Figures 6 and 7); indeed give support to the hypothesis that a given dose of glyphosate, under a given management practice, can be especially harmful to seed quality. For these same variables there was not statistically significant differences $(\mathrm{p} \leq 0.05)$ within the splitting performed, being possible to notice the discrimination for the main effect of stages (length of seedlings and roots) and for the main effects of dosages in the best-fit of the regression model computed (length, and fresh and dry mass of seedlings).

Therefore, sprays performed during reproductive stage may compromise seedlings performance (Table 3 ) and the doses of 1,440 $\mathrm{g} \mathrm{ha}^{-1}$ and 2,880 $\mathrm{g} \mathrm{ha}^{-1}$ are prejudicial to seedling development, independent of stage in which the herbicide was applied in the experiment (Figures 5, 6, and 7).

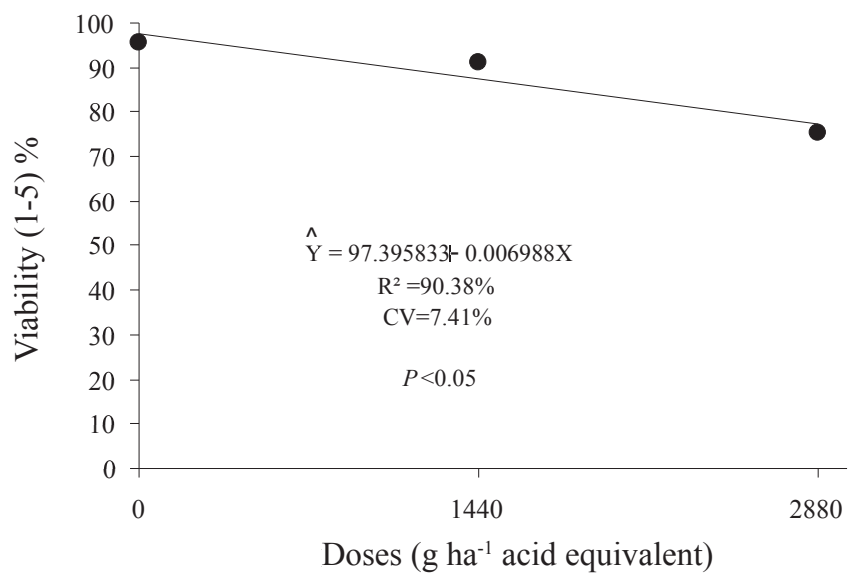

Figure 4. Linear regression for the viability variable (1-5) assessed by tetrazolium test in seeds of RR transgenic soybean, cultivar CD 219RR, as a function of application of different doses of glyphosate at soybean reproductive stage $\mathrm{R} 2$.

On Table 5, the means for the total of fungi quantified in seeds harvested after treatment with the herbicide different doses, and the mean percent values for each fungus species, evaluated within each treatment, can be observed. It is perceptible that for the parameter seed health quality, it was not possible to detect statistically significant differences, at $5 \%$ probability, either for the total of fungi or for each pathogenic fungal species quantitatively discriminated.

The results for seed health obtained in this work do not corroborate the results reported by Albrecht and Ávila (2010). These authors have found increases on incidence of the fungus Cercospora kikuchii in seeds, after application of increasing doses of glyphosate on the early soybean cultivar CD 214RR. They have also identified increase on the total percentage of fungi as well as on incidence of the fungus Fusarium semitectum on RR soybean seeds when the doses of glyphosate, in grams of acid equivalent per hectare, 
where higher than $720 \mathrm{~g}$. These differences on results may probably be explained by the differences of climatic conditions prevailing during the carrying out of this study, which might have influenced, or not, higher susceptibility to incidence of pathogenic fungi in the seeds (Marcos-Filho, 2005) and also to differences among the genotypes assessed.

Table 3. Mean values for lengths of seedlings and roots obtained for seedlings of transgenic soybean RR, cultivar CD 219RR, after the first count of germination test performed in seeds harvested after application of different doses of glyphosate in two different soybean phenological stages (V6 and R2).

\begin{tabular}{ccccc}
\hline & \multicolumn{2}{c}{$\begin{array}{c}\text { Length of seedling } \\
(\mathrm{cm})\end{array}$} & \multicolumn{2}{c}{$\begin{array}{c}\text { Length of root } \\
(\mathrm{cm})\end{array}$} \\
\cline { 2 - 5 }$\left(\mathrm{g} \mathrm{ha}^{-1}\right)$ & Vegetative & Reproductive & Vegetative & Reproductive \\
& $\mathrm{V} 6$ & $\mathrm{R} 2$ & 6.73 & $\mathrm{R} 2$ \\
\hline 0 (control) & 12.4 & 11.06 & 6.55 & 5.50 \\
1,440 & 10.75 & 11.53 & 6.37 & 5.94 \\
2,880 & 10.07 & 9.49 & $6.55 \mathrm{~A}^{*}$ & 5.77 \\
\hline Mean & $11.28 \mathrm{~A}^{*}$ & $10.69 \mathrm{~B}^{*}$ & $\mathrm{~B}^{*}$ \\
\hline
\end{tabular}

*Means followed by the same letter in the line do not statistically differ between each other by the $\mathrm{F}$ test at $5 \%$ probability.

Table 4. Mean values for fresh and dry mass of seedling obtained for seedlings of transgenic soybean RR, cultivar CD 219RR, after the first count of germination test performed in seeds harvested after application of different doses of glyphosate in two different soybean phenological stages (V6 and R2).

\begin{tabular}{ccccc}
\hline \multirow{2}{*}{$\begin{array}{c}\text { Dose } \\
\left(\mathrm{g} \mathrm{ha}^{-1}\right)\end{array}$} & \multicolumn{2}{c}{ Fresh mass $(\mathrm{g})$} & \multicolumn{2}{c}{ Dry mass $(\mathrm{g})$} \\
\cline { 2 - 5 } & Vegetative & Reproductive & Vegetative & Reproductive \\
\hline 0 (control $)$ & 16.03 & R2 & 3.21 & 3.18 \\
1,440 & 14.80 & 15.92 & 2.96 & 3.09 \\
2,880 & 13.20 & 15.47 & 2.64 & 2.70 \\
\hline Mean & $14.68^{\text {ns }}$ & 13.49 & $2.94^{\text {ns }}$ & $2.99^{\text {ns }}$ \\
\hline
\end{tabular}

ns $=$ non significant

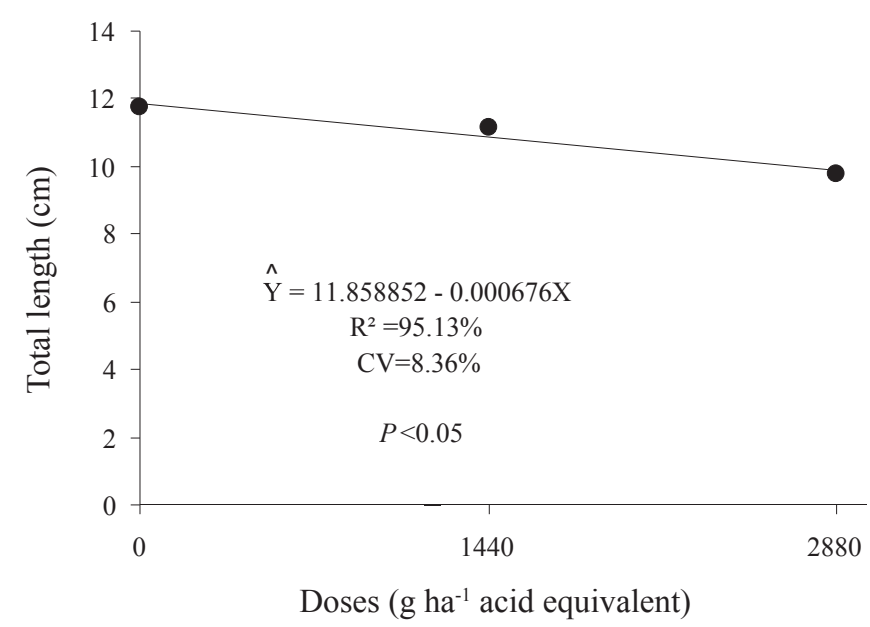

Figure 5. Linear regression for the variable total length of seedling, assessed in seedlings of RR transgenic soybean, cultivar CD 219RR, as a function of application of different doses of glyphosate.

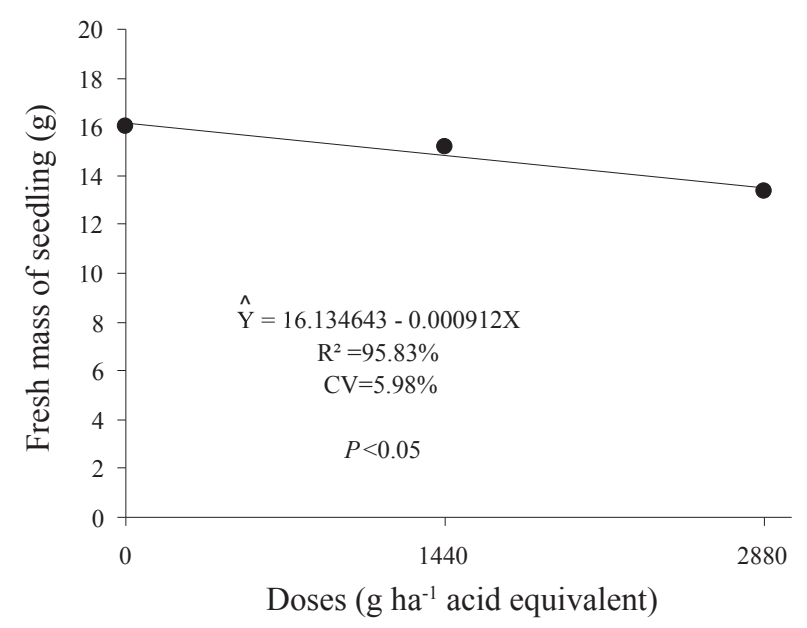

Figure 6. Linear regression for the variable fresh mass of seedlings, assessed in seedling of RR transgenic soybean, cultivar CD 219RR, as a function of application of different doses of glyphosate. 


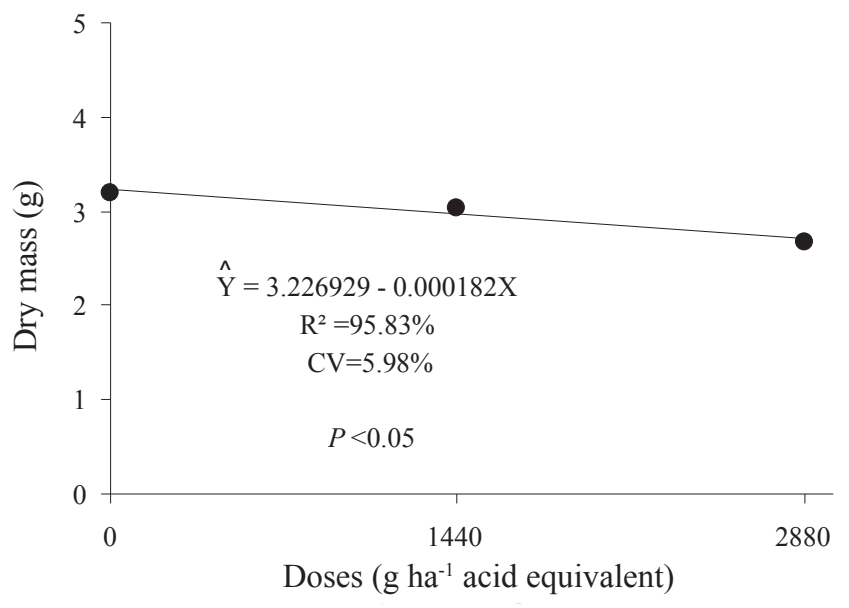

Figure 7. Linear regression for the variable dry mass of seedlings, assessed in seedling of RR transgenic soybean, cultivar CD 219RR, as a function of application of different doses of glyphosate.

The negative effects, characterized by seed physiological quality, are probably related to potential of damage, or deleterious action of glyphosate, as found in the pertaining literature (Reddy et al. 2004; Gordon, 2006; Huber, 2007;
Zobiole et al. 2009; Zobiole et al. 2010a; Zobiole et al. 2010b). Results herein obtained, however, corroborate the synthesis of research works analyzed by Albrecht and Ávila (2010), who have stressed the perceptible and significant influences of post-emergence application of glyphosate on RR transgenic soybean cultivars.

The glyphosate can cause stress even on RR transgenic soybean plants for which it should be selective, i.e., should not have herbicide effect, but can have phytotoxic action affecting the efficiency in the water use, the photosynthesis, and the nutritional balance (Zobiole et al. 2010a; Zobiole et al., 2010b; Zobiole et al. 2009; Albrecht and Ávila, 2010). Any stress induces negative effect on normal growth and on development of plant species (Taiz and Zeiger, 2009). There are probable consequences in using post-emergence application of glyphosate on the RR soybean crop, such as direct changes in the mineral nutrition of plants, as in the case of the $\mathrm{Mn}$, as well as for other nutrients, as $\mathrm{N}, \mathrm{Ca}, \mathrm{Mg}$, $\mathrm{Fe}$, and $\mathrm{Cu}$, which may have their levels altered with glyphosate application (Gordon, 2006; Huber, 2007; Santos et al., 2007a; Santos et al., 2007b).

Table 5. Percentage of mean values obtained for the total fungi and for each pathogenic fungal species found in seeds of transgenic soybean RR, cultivar CD 219RR, during the germination test. Data obtained from seeds harvested after application of different doses of glyphosate in two different soybean phenological stages.

\begin{tabular}{cccccccc}
\hline $\begin{array}{c}\text { Phenological } \\
\text { stage }\end{array}$ & $\begin{array}{c}\text { Dose } \\
\left(\mathrm{g} \mathrm{ha}^{-1}\right)\end{array}$ & $\begin{array}{c}\text { Total } \\
\text { fungi } \\
(\%)\end{array}$ & $\begin{array}{c}\text { Phomopsis sp. } \\
(\%)\end{array}$ & $\begin{array}{c}\text { Cercospora } \\
\text { kikuchii } \\
(\%)\end{array}$ & $\begin{array}{c}\text { Fusarium } \\
\text { semitectum } \\
(\%)\end{array}$ & $\begin{array}{c}\text { Aspergillus } \\
\text { spp. } \\
(\%)\end{array}$ & $\begin{array}{c}\text { Colletotrichum } \\
\text { dematium var. } \\
\text { truncata } \\
(\%)\end{array}$ \\
\hline \multirow{2}{*}{ V6 } & 0 & 15.75 & 1.19 & 2.81 & 11.38 & 0.25 & 0.13 \\
& 1,440 & 17.00 & 0.44 & 3.44 & 12.88 & 0.13 & 0.13 \\
& 2,880 & 14.81 & 0.69 & 3.38 & 10.56 & 0.13 & 0.06 \\
\hline \multirow{2}{*}{ R2 } & 0 & 16.00 & 0.44 & 3.25 & 11.69 & 0.38 & 0.25 \\
& 1,440 & 15.99 & 3.06 & 3.81 & 10.13 & 1.06 & 0.44 \\
\hline
\end{tabular}

It is known that also RR soybean plants may keep the residues of AMPA, which is a phytotoxic sub-product from glyphosate degradation (Reddy et al., 2004), that accumulate in the seeds (Duke et al., 2003). The increase in the glyphosate dose can lead to elevation of AMPA content, thus enhancing the phytotoxic effect of such metabolite (Reddy et al., 2004) that besides other plant physiological changes (Zobiole et al, 2010b) can directly affect soybean crop performance.

Stressors that cause changes on soybean physiology, such as glyphosate, can interfere on the processes leading to formation and development of the seeds, hence affecting the viability and vigor of such seeds. Therefore, the late application of glyphosate (stage V6) and the glyphosate application performed during a non-recommended period (stage R2), in the high doses of 1,440 $\mathrm{g} \mathrm{ha}^{-1}$ and 2,880 $\mathrm{g} \mathrm{ha}^{-1}$ of acid equivalent, were detrimental to physiological performance of RR transgenic soybean, cv. CD 219 RR, due to its direct injurious action or the action of its metabolites, such as the AMPA, on seed physiology. 


\section{Conclusions}

The herbicide glyphosate can negatively affect the physiological quality of RR soybean seeds, cultivar 219RR $\mathrm{CD}$, when applied in doses ranging from 1,440 to $2,880 \mathrm{~g}$ acid equivalent per hectare during the stage of vegetative development V6 and reproductive stage R2 of the soybean crop.

\section{References}

ALBRECHT, L.P.; ÁVILA, M.R. Manejo de glyphosate em soja RR e a qualidade das sementes. Informativo Abrates, v.20, n.2, p.45-54, 2010. http://www.abrates.org.br/downloads/informativo/v20n12/artigo06.pdf

ARREGUI, M.C.; LENARDÓN, A.; SANCHEZ, D.; MAITRE, M.L.; SCOTTA, R.; ENRIQUE, S. Monitoring glyphosate residues in transgenic glyphosate-resistant soybean. Pest Management Science, v.60, p.163-166, 2003. http://onlinelibrary.wiley.com/journal/10.1002/(issn)1526-4998

BRASIL. Ministério da Agricultura, Pecuária e Abastecimento. Regras para análise de sementes. Ministério da Agricultura, Pecuária e Abastecimento. Secretaria de Defesa Agropecuária. Brasília: MAPA/ACS, 2009. 395p. http://www.bs.cca.ufsc.br/publicacoes/regras\%20analise\%20sementes.pdf

DUKE, S.O.; RIMANDO, A.M.; PACE, P.F.; REDDY, N.K.; SMEDA, R.J. Isoflavone, glyphosate, and aminomethylphosphonic acid levels in seeds of glyphosate-treated, glyphosateresistant soybean. Journal of Agriculture and Food Chemistry, v.51, p.340-344, 2003. http://pubs.acs.org/journal/jafcau

EMBRAPA SOJA. Tecnologias de produção de soja - região central do Brasil - 2008. Londrina: Embrapa Soja; Embrapa Cerrados; Embrapa Agropecuária Oeste, 2008. 280p. (Sistemas de Produção, 12). http:// www.cnpso.embrapa.br/download/tpsoja_2008.pdf

FRANÇA-NETO, J.B.; KRZYZANOWSKI, F.C.; COSTA, N.P. O teste de tetrazólio em sementes de soja. Londrina: EMBRAPA-CNPSo, 1998. 72p. (Documentos, 116). http://www.cnpso.embrap3,a.br/download/pdf/ cirtec39_sementes.pdf

FRANÇA-NETO, J.B.; HENNING, A.A. Diacom: diagnóstico completo da qualidade da semente de soja. Londrina: EMBRAPA Soja, 1992. 21p. (Circular Técnica, 10).

GORDON, B. Manganese nutrition of glyphosate-resistant and conventional soybeans. In: Great Plains Soil Fertility Conference Proceeding. Denver, CO, March 7-8, 2006, p.224-226.

GORDON, B. Adubação com manganês em soja convencional e soja resistente ao glyphosate. Informações Agronômicas, n.117, p.6, 2007. http:// www.potafos.org/ppiweb/brazil.nsf/\$webindex/article=ba18d99a032570b5 00729fa92b92f632?opendocument\&navigator $=$ informacoes+agronomicas

GOULART, A.C.P. Fungos em sementes de soja: detecção e importância. Dourados: Embrapa-CPAO, 1997. 58p. (Documentos, 11).
HENNING, A.A.; FRANÇA-NETO, J.B. Problemas na avaliação de germinação de sementes de soja com alta incidência de Phomopsis $s p$. Revista Brasileira de Sementes, v.2, n.5, p.9-22, 1980.

HENNING, A.A. Patologia de sementes. Londrina: EMBRAPA Soja, 1994. 43p. (Documentos, 90).

HOAGLAND, R.E. Effects of glyphosate on metabolism of phenolic compounds: VI. Effects of glyphosate and glyphosate metabolites on phenylalanine ammonia-lyase activity, growth, emd protein, chlorophyll, and anthocyanin levels in soybean (Glycine max) seedling. Weed Science, v.28, p.393-400, 1980. http://www.jstor.org/pss/4043243

HUBER, D.M. What about glyphosate-induced manganese deficiency. Fluid Journal, p.20-22, 2007. http://www.agweb.com/assets/import/ files/58P20-22.pdf

MARCOS-FILHO, J. Fisiologia de sementes de plantas cultivadas. Piracicaba: FEALQ, 2005. 495p.

NAKAGAWA, J. Testes de vigor baseados no desempenho das plântulas. In: KRZYZANOWSKI, F.C.; VIEIRA, R.D.; FRANCA-NETO, J.B. (Ed.). Vigor de sementes: conceitos e testes. Londrina: ABRATES, 1999. p.2.1-2.24

PEREIRA, E.B.C.; PEREIRA, A.V.; FRAGA, A.C. Qualidade de sementes de cultivares precoces de soja produzidas em três épocas. Pesquisa Agropecuária Brasileira, v.35, n.8, p. 1653 - 1662, 2000. http:// www.scielo.br/pdf/pab/v35n8/v35n8a19.pdf

RAHE, J.E. O herbicida glyphosate - como ele mata as plantas? Informações Agronômicas, n.117, p.6, 2007. http://www.inpofos.org/ ppiweb/brazil.nsf/87cb8a98bf72572b8525693e0053ea70/d20fb44d8525 9bf7032572530062870e/\$file/parte-heitor.pdf

REDDY, K.N.; RIMANDO, A.M.; DUKE, S.O. Aminomethylphosphonic acid, a metabolite of glyphosate, causes injury in glyphosate-treated, glyphosate-resistant soybean. Journal of Agriculture and Food Chemistry, v.52, p.5139-5143, 2004. http://ddr.nal.usda.gov/bitstream/10113/8258/1/ ind43640449.pdf

REDDY, K.N.; ZABLOTOWICZ, R.M. Glyphosate-resistant soybean response to various salts of glyphosate and glyphosate accumulation in soybean nodules. Weed Science, v.51, p.496-502, 2003. http://www.bioone. org/doi/abs/10.1614/00431745(2003)051\%5b0496:gsrtvs\%5d2.0.co\%3b2

RIZZARDI, M.A.; FLECK, N.G.; AGOSTINETTO, D.; BALBINOT JR.; A.A. Ação de herbicidas sobre mecanismos de defesa das plantas aos patógenos. Ciência Rural, v.33, n.5, p.957-965. 2003. http://www.scielo.br/ scielo.php?pid=s010384782003000500026\&script=sci_arttext\&tlng=es

SANTOS, J.B.; FERREIRA, E.A.; REIS, M.R.; SILVA, A.A.; FIALHO, C.M.T.; FREITA, M.A.M. Avaliação de formulações de glyphosate sobre soja Roundup Ready. Planta Daninha, v.25, n.1, p.165-171, 2007a. http:// www.scielo.br/scielo.php?pid=S0100-83582007000100018\&script=sci arttext\&tlng=in

SANTOS, J.B., FERREIRA, E.A., OLIVEIRA, J.A.; SILVA, A.A; FIALHO, 
C.M.T. Efeito de formulações na absorção e translocação do glyphosate em soja transgênica. Planta Daninha, v. 25, n.2, p.381-388, 2007b. http://www.scielo. br/scielo.php?pid=S0100-83582007000200019\&script=sci_arttext\&tlng=es/

TAIZ, L.; ZEIGER. Fisiologia vegetal. 4.ed. Porto Alegre: Artmed, 2009. 819p.

ZOBIOLE, L.H.S.; OLIVEIRA JUNIOR, R.S.; KREMER, R.J.; CONSTANTIN, J.; YAMADA, T.; CASTRO, C.; OLIVEIRA, F.A.; OLIVEIRA JUNIOR, A. Effect of glyphosate on symbiotic N2 fixation and nickel concentration in glyphosate-resistant soybeans. Applied Soil Ecology, v.44, n.2, p.176-180, 2010a. http://ddr.nal.usda.gov/ bitstream/10113/39648/1/ind44313688.pdf
ZOBIOLE, L.H.S.; OLIVEIRA JUNIOR, R.S.; KREMER, R.J.; CONSTANTIN, J.; BONATO, C.M.; MUNIZ, A.S. Water use efficiency and photosynthesis of glyphosate-resistant soybean as affected by glyphosate. Pesticide Biochemistry and Physiology, v.97, n.3, p.182-193, 2010b. http://www.dag.uem.br/napd/up/publicnapd e520f7bc2ecf23fc44f3766ea09ddf13ohzkw.pdf

ZOBIOLE, L.H.S.; OLIVEIRA JUNIOR, R.S.; HUBER, D.M.; CONSTANTIN, J.; CASTRO, C.; OLIVEIRA, F.A.; OLIVEIRA JUNIOR, A. Glyphosate reduces shoot concentrations of mineral nutrients in glyphosate-resistant soybeans. Plant and Soil, v.321, p.4, 2009. http://www.springerlink.com/content/b1148822214w7341/ 